\title{
Samotność osób starszych i czynniki ją warunkujące
}

\begin{abstract}
In the common opinion, old age is still a taboo. Among the variety of the difficulties experienced by the elderly, there are also an increasingly occurring struggle with acclimating to the aging, and a sense of being a burden. The article focuses on the issue of loneliness, especially among elderly people. It is also an attempt to answer the questions of whether the old people experience loneliness, and what are the factors that affect this condition. In order to reply to these questions, the author attempted an analysis of the issues basing on literature, using theoretical analysis data and the earlier research.
\end{abstract}

\section{Keywords:}

old age, multi-faceted aging, loneliness, types of solitude, being alone, the value of solitude, ,active ageing”

Starość i samotność nie są tematami, o których z chęcią się rozmawia. W społecznym odbiorze zagadnienia te stanowią zdecydowanie temat tabu, zwłaszcza jeśli koncentrują się wokół niepełnosprawności, niedołężności czy trudności ekonomicznych. Coraz częściej podejmowane dyskusje odnoszą się raczej do kreowa-

1 Małgorzata Fopka-Kowalczyk, Katedra Opieki, Profilaktyki i Resocjalizacji, Wydział Nauk Pedagogicznych, Uniwersytet Mikołaja Kopernika w Toruniu, Polska, malgorzata.j.kowalczyk@ gmail.com. 
nia obrazu osób starszych świetnie radzących sobie z codziennymi zadaniami, wypełniających dni aktywnością lub realizowaniem własnych pasji i zainteresowań. Niechętnie lub żartem natomiast podejmuje się temat wielochorobowości, doświadczanych trudności i skarg w okresie starości. Trudno zaprzeczyć, że w każdym wieku mogą występować określone problemy, specyficzne dla danego okresu rozwojowego. Jednym ze stanów może też być doświadczanie samotności, ponieważ: „dosięga nas wszystkich bez względu na wiek czy pozycję społeczną” (Kusztelak, 2009, s. 279). Starość wydaje się okresem niejako predysponującym wystąpienie samotności, stanowiąc trudną sytuację, zwłaszcza jeśli nie jest to samotność z wyboru.

Niniejszy tekst koncentruje się wokół zagadnienia doświadczania samotności, zwłaszcza wśród ludzi w podeszłym wieku, i jest próbą odpowiedzi na pytania, czy osoby starsze odczuwają samotność i jakie czynniki stają się faktorami wpływającymi na doświadczanie tego stanu. W tym celu autorka tekstu podjęła próbę analizy zagadnienia w oparciu o literaturę przedmiotu, korzystając $\mathrm{z}$ analizy istniejących danych teoretycznych i przeprowadzonych wcześniej badań.

\section{STAROŚĆ}

Ludzie starzejący się w Polsce (a wydaje się, że i na świecie) doświadczają szerokiego wachlarza trudności w większości sfer swojego funkcjonowania. W oparciu o literaturę przedmiotu można wskazać, że: „szczególnie charakterystyczne są dla tego okresu życia ograniczenia sprawności fizycznej i psychicznej oraz rozluźnienie kontaktów społecznych” (Tokaj, 2014, s. 403). Należy zaznaczyć, że starość jest procesem indywidualnym i nie przebiega u każdego w sposób jednakowy. Trajektoria starzenia się uzależniona jest od różnorodnych faktorów związanych z zachodzącymi procesami biologicznymi i psychicznymi oraz ze zmianami w relacjach społecznych. „Wśród radości uniwersalnych są i takie, które wynikają z subiektywnej perspektywy postrzegania życia - jego sensu i finalnie wypracowanych, w drodze do starości, kompetencji radowania się nim” (Tokaj, 2014, s. 402). Zdecydowane znaczenie mogą mieć także występujące choroby i ich uciążliwość w codziennym funkcjonowaniu osób starszych, poziom sprawności i samodzielność oraz stopień konieczności korzystania z opieki/pomocy innych. Dodatkowym stresorem może być również fizyczna nieobecność bliskich przez ich wyjazdy z miasta/kraju, rzadkie odwiedziny lub też przewlekłe przeżywanie straty z powodu śmierci bliskich, znajomych, sąsiadów czy przyjaciół. Każdy z wyróżnionych czynników może potęgować trudności związane z przystosowa- 
niem się do starzenia się i starości. Innym ważnym elementem wpływającym na jakość przeżywanej starości jest osobowość osoby starszej, dotychczasowy sposób funkcjonowania i radzenia sobie w trudnych sytuacjach oraz postawa do starości. Postawa pozytywna, ukierunkowana na aktywność, zmniejsza dolegliwości związane ze starzeniem się, natomiast negatywna staje się często podstawą do wystąpienia różnorodnych emocji, w tym także negatywnych, odizolowywaniu się i niechęci do otoczenia i samego siebie. „Na horyzoncie senioralnego bytu, obok chwil radosnych potęgujących pragnienie życia, ujawniają się obiektywne i subiektywne trudności. Doświadczanie ich niesie ze sobą biegunowo przeciwstawny radości stan. Pojawia się smutek schyłku życia - dostrzec go można w niepokoju, w rozczarowaniu seniora, w wyrażanym poczuciu krzywdy czy też, zapewne najsilniej, w odczuwanym przez niego postaci wielopostaciowym cierpieniu” (Tokaj, 2009, s. 403).

Zdrowie jest jedną z największych wartości każdego człowieka. W trakcie dojrzewania i całego życia znaczna większość gatunku ludzkiego stara się dbać o swoją sprawność i zdrowie. W większości przypadków nie zmienia się to na starość, kiedy znaczenia nabiera umiejętność zadbania o siebie, bycie samodzielnym w podstawowych czynnościach dnia codziennego. Każde upośledzenie dotychczasowej sprawności skutkować może nie tylko zrozumiałym niezadowoleniem i frustracją, ale też niechęcią do aktywności, złością na siebie, a także wycofywaniem się z relacji interpersonalnych. Omawiana szeroko wielochorobowość (Wieczorkowska-Tobis, 2011) jest jedną z najbardziej charakterystycznych cech w przebiegu starości. Oprócz mniej dotkliwych dolegliwości jak „strzykanie w kościach” czy „gorszy wzrok i słuch” pojawiają się objawy poważnych i przewlekłych chorób, trudnych często do opanowania i leczenia, które często współtowarzyszą podstawowej chorobie. Należy wspomnieć, że w procesie starzenia się organizmu najczęściej występują m.in.: demencje (zespoły otępienne), choroby zwyrodnieniowe stawów z osteoporozą, upośledzenia zmysłu wzroku i słuchu, depresje. Bardzo często ma miejsce sytuacja, kiedy opisane symptomy - i wiele innych - występują jednocześnie lub też jedna choroba podstawowa wywołuje niejako pojawienie się objawów innych chorób. Taki stan rzeczy z kolei wzmaga niepełnosprawność, konieczność opieki i troski, a ostatecznie - różnorodne reakcje emocjonalne osób starszych na zastaną sytuację.

W procesie starzenia się pojawia się jeszcze inna ważna kwestia. Wydawałoby się, że po okresie wychowywania dzieci i dbania o dom osoba starsza będzie otrzymywała wsparcie, troskę i pomoc w czasie, gdy tego najbardziej potrzebuje. Statystyki i realia pokazują jednak zupełnie odwrotną sytuację. Z różnych przyczyn nie ma często szans na funkcjonowanie w relacjach rodzinnych czy 
też otrzymywania oczekiwanego wsparcia i opieki. Dochodzi do sytuacji, gdy starszy człowiek zaczyna odczuwać osamotnienie czy też samotność, nie mając blisko siebie nikogo ważnego emocjonalnie lub też żyje wśród innych, mając poczucie niezrozumienia i emocjonalnej bliskości. Wzrasta wtedy poczucie osamotnienia i jak najbardziej częste jest poczucie odrzucenia i poczucie bycia bezwartościowym. Dodatkowy kłopot pojawia się, gdy człowiek stary z różnych względów zmuszony jest do opuszczenia swojego dotychczasowego miejsca pobytu. „Psychiczne koszty przeprowadzki dotyczą jednego z ważniejszych aspektów poczucia tożsamości - przywiązania do miejsca” (Hauziński, 2007, s. 115). Starzejący się organizm oraz umieranie najbliższych osób w otoczeniu osoby starszej budzi refleksję na temat śmierci i umierania. Najczęściej jest to powiązane z występującą obawą przed osobistym umieraniem jako stanem, ale również przed bólem, cierpieniem i umieraniem w samotności (Tokaj, 2014, s. 409). Straś-Romanowska (1999, s. 78) wskazuje w swoich badaniach, że doświadczana strata przez osoby starsze obejmuje przeżywaną żałobę po utraconej młodości i sprawności oraz atrakcyjności własnej - fizycznej i społecznej. Osoba starzejąca się doświadcza straty także w kontekście utraconej pozycji zawodowej i społecznej. Wizja odejścia z pracy i przejścia na emeryturę, poczucie bycia niepotrzebnym czy też samotność wywołana brakiem bliskości dzieci budzi znaczący niepokój i lęk o swoją pozycję i rolę w mikroświecie. „Współcześnie nauki społeczne zwracają uwagę na nasilenie zjawiska, w którym osoby starsze tracą na znaczeniu w relacjach z innymi, ponieważ mają niewiele do zaoferowania” (Szyszkowski, 2013, s. 489). Dodatkowym czynnikiem jest nieustanny dynamiczny wzrost rozwoju technologii i gospodarki (obsługa komputera czy telefonu), za którym nie każda starsza osoba nadąża.

Wymienione wyżej czynniki mogą stać się podstawą do odczuwania przez osoby starsze różnorodnych stanów emocjonalnych i reagowania na coraz bardziej namacalny proces starzenia się. Podejmowane niekiedy środki zapobiegawcze minimalizują odczuwany lęk, jednak wydaje się zasadnym twierdzenie, że „nawet najbardziej adaptacyjna aktywność nie zapobiega i nie eliminuje koniecznych strat” (Oleś, 2011, s. 170). Ilość nagromadzonych i kumulujących się doświadczeń i utrat może w konsekwencji doprowadzić do odczuwanych emocji, między innymi dotkliwej samotności i osamotnienia. 


\section{SAMOTNOŚĆ JAKO ZJAWISKO SPOŁECZNE}

Literatura przedmiotu traktująca o samotności prezentuje kilkanaście różnych jej definicji. Poniżej przedstawiono kilka wybranych, najbardziej zdaniem autorki wpisujących się w zagadnienia prezentowane w tekście. Jedna z nich mówi, że samotność to: „odczuwany stan braku towarzystwa bliskiej osoby, opuszczenia przez innych; bycie samotnym, przebywanie w odosobnieniu bez rodziny, przyjaciół” (Dunaj, 1999, s. 528). W psychologii samotność definiowana jest jako: „subiektywne, nieprzyjemne, bolesne przeżycie, wynikające z braku pozytywnych relacji w stosunkach międzyludzkich” (Kusztelak, 2009, s. 280). Za Stochmiałkiem można powiedzieć natomiast, że samotność to: „przeżycie przykre, ujemnie wpływające na zdrowie i kondycję fizyczną i psychiczną [...] Jest mieszaniną uczuć odrzucenia, braku akceptacji i nieprzyjemnych przeżyć. Z reguły towarzyszą jej: gniew, rozczarowanie, poczucie nieszczęścia i pesymizm” (2005, s. 30).

Jundziłł i Pawłowska (2000, s. 24) analizują samotność w kontekście deficytu uczuć odczuwanego przez osobę samotną. Autorki wyróżniają trzy poziomy samotności: 1) samotność w kontekście kontaktów z innymi ludźmi - im bardziej powierzchowne i „nijakie” relacje, tym częściej odczuwana samotność i poczucie izolacji; 2) samotność w kontekście bycia w myślach i pamięci innych - im mniej jesteśmy pamiętani i zauważani przez otoczenie, tym częściej dochodzi do odczuwanej samotności; 3) samotność w kontekście bycia traktowanym instrumentalnie - brak poczucia relacji podmiotowych oraz przekonanie o instrumentalnym wykorzystaniu potęguje poczucie samotności człowieka.

Omawiając zagadnienie samotności używa się często synonimów lub też zamienników na oznaczenie tego stanu takich jak: izolacja, alienacja, osamotnienie, odosobnienie, wyobcowanie, odizolowanie, wykorzenienie (Kusztelak, 2009, s. 280).

Analizując powyższe definicje można przedstawić czynniki, które przyczyniają się do zwiększonego poczucia samotności, zwłaszcza w odniesieniu do osób starszych. Jak łatwo zauważyć, wybrane i przedstawione faktory pokrywają się w znacznej mierze z symptomami i przeżyciami związanymi z procesem starzenia się człowieka. „Przyczyny samotności [...] można porządkować w kategoriach społecznych, psychologicznych, kulturowych i w zależności od dominujących czynników eksponować te lub inne jako najważniejsze” (Gajda, 1997, s. 188). Wśród przyczyn społecznych wyróżnić można miejsce zamieszkania i możliwość oraz jakość kontaktów z innymi, wykształcenie, opinia w środowisku, uroda (zwłaszcza widoczne defekty i kalectwo), również sytuacja społeczno-zawodowa i materialna. Spośród przyczyn psychologicznych najważniejszymi wydają się: 
kompleks niższości, nieumiejętność nawiązywania kontaktów, wygórowany ideał miłości. Znaczenie mają także cechy temperamentalne jak introwertyzm i ekstrawertyzm (Gajda, 1997).

Wśród innych czynników mających wpływ na występowanie poczucia samotności wyróżnić można następujące:

1. Pierwszym z elementów jest sposób traktowania starości przez społeczeństwo, odbiór społeczny, stereotypy - łączenie starości z niedołężnością i niepełnosprawnością sprawia, że na samym już wstępie osoby starsze są odrzucane jako ewentualni partnerzy czy kandydaci do współpracy lub aktywności.

2. Osoby starsze przez zwiększającą się niepełnosprawność same odsuwają się od aktywności i współuczestniczenia w relacjach społecznych, co wzmaga ich poczucie izolacji i samotności.

3. Umieszczanie osób starszych w zamkniętych zakładach całodobowych wzbudza u osób starszych poczucie odrzucenia i marginalizacji (Gutka, 2013).

4. Zgodnie z literaturą przedmiotu, nie można zapomnieć, że odczuwany stan zależny jest zarówno od czynnika kulturowego, jak i demograficznego (Szukalski, 2003).

5. Posiadanie rodziny nie stanowi zabezpieczenia przed poczuciem bycia osamotnionym, chociaż może z pewnością stanowi czynnik pomocny, aby samotności nie odczuwać (Janiszewska, Barańska, 2013).

6. Przyczyną samotności są przede wszystkim izolacja społeczna lub zakłócone relacje międzyludzkie (Olearczyk, 2007).

7. Do innych faktorów zaliczyć można także samotność kulturową, samotny styl życia, utratę najbliższych, świadomość nieuchronnej śmierci (Rembowski, 1992). Innym powodem, wydaje się najczęściej występującym wśród ludzi starzejących się, jest proces degradacji funkcji organizmu, występujące choroby - zarówno psychiczne, jak i fizyczne, jak również świadomość nieuchronnej śmierci (Dąbrowska, 1992).

8. Jeszcze jednym, ważnym współcześnie czynnikiem związanym z rozwojem i postępem, jest zjawisko wykluczenia społecznego i związanymi z wykluczeniem stereotypami na temat osób starych jako osób niedołężnych, mniej przydatnych i poddanych marginalizacji zawodowej i towarzyskiej (Dąbrowska, 1992). 


\section{TYPY SAMOTNOŚCI. SAMOTNOŚĆ I OSAMOTNIENIE}

W oparciu o zaprezentowane definicje oraz literaturę przedmiotu można wskazać na różne rodzaje i typy samotności. Zasadniczym podziałem jest rozróżnienie na samotność i osamotnienie, przy czym samotność odnosi się do czysto fizycznego stanu, natomiast osamotnienie - zwane też samotnością psychiczną - ma miejsce w sytuacji, gdy osoba doświadcza jej subiektywnie (Kusztelak, 2009). Rozróżnienie obu pojęć uzależnione jest od przyjmowanego przez danego autora kryterium.

Samotność można również podzielić na krótkotrwałą i chroniczną (Charchut, 2013), w zależności od długości jej trwania. Jeśli nie trwa ona długo i mamy do czynienia z konkretną sytuacją wpływającą na człowieka, to dochodzi do samotności krótkotrwałej. Czasem jednak nie ma czynnika zmniejszającego poczucie samotności i nie mija ono po krótkim czasie, lecz utrzymuje się na stałym poziomie - w takiej sytuacji możemy mówić o samotności chronicznej.

Innym interesującym podziałem samotności jest rozróżnienie na samotność fizyczną, psychiczną i moralną. Z samotnością fizyczną mamy do czynienia w sytuacji izolacji społecznej np. przez osłabienie więzi z innymi ludźmi, zwłaszcza z osobami znaczącymi. Z samotnością psychiczną mamy do czynienia w sytuacji odczuwanego braku więzi z innymi, natomiast z moralną, gdy człowiek traci sens życia, brakuje mu wzorów do naśladowania i ideałów i nie może normalnie funkcjonować (Charchut, 2013, s. 18-19; Kusztelak, 2009, s. 283-284). Taka sytuacja doprowadza do szeregu negatywnych przeżyć i odczuć u osoby jej doświadczającej.

Szczególnie interesującym ze względu na podejmowaną tematykę jest typologia zaproponowana przez Klimowicz (1988). W swoich analizach proponuje ona następujące typy samotności, uzależniając ich występowanie od źródła je wywołującego: a) samotność interpersonalna - „tęsknota do...” wywołana śmiercią i odchodzeniem bliskich osób, b) samotność społeczna - wywołana izolacją lub odrzuceniem przez otoczenie, c) samotność kulturowa - przez poczucie bycia innym w kontekście życia w grupie, d) samotność kosmiczna - polegająca na byciu „poza” sensem, odczuwaną beznadziejnością i bezsensem życia, e) samotność psychologiczna - przeżywanie wyobcowania od własnego „ja”. Wyróżniony podział wydaje się szczególnie odpowiedni, kiedy spróbujemy go odnieść do doświadczeń osób starszych. Każda z wyróżnionych kategorii może być przypisana przeżyciom osób w podeszłym wieku.

Rozważając zagadnienie samotności, należy przypomnieć, że czasem jest to stan świadomie wybierany przez niektóre osoby, jakby doświadczany przez niektórych z własnej woli. Może się przecież zdarzyć tak, że samotność postrzegana 
jest jako wartość. Ma to miejsce zwłaszcza w sytuacji, gdy doświadczany stan wynika z decyzji podjętej indywidualnie przez osobę. Zdaniem niektórych autorów, dobra samotność ma miejsce wtedy, gdy człowiek ma nad nią poczucie kontroli i może ten stan w każdej chwili zmienić. Jeśli jednak jest to sytuacja długotrwała, nad którą trudno jest zapanować i która nie mija bądź też trwa mimo innej potrzeby człowieka, wtedy jest odczuwana jako balast, ciężar, utrudnienie, a nawet niechciane cierpienie (Charchut, 2013). Adekwatnie do powyższych rozważań warto przypomnieć, że literatura przedmiotu wskazuje na dwie główne kategorie teoretyczne: samotność i osamotnienie. W literaturze gerontologicznej te dwie definicje traktuje się jako dwa odmienne stany: samotność jako stan obiektywny; osamotnienie - jako doświadczenie subiektywne (Szukalski, 2003).

Samotność definiowana jest jako stan obiektywny, sytuacja powstała na skutek długotrwałego pozostawania bez kontaktów międzyludzkich, wywołana brakiem możliwości kontaktu fizycznego na skutek braku więzi społecznych z innym. Dodatkową przyczyną mogą być źle lub nieadekwatnie do oczekiwań pełnione role społeczne. Osamotnienie natomiast kojarzone jest raczej ze stanem poczucia izolacji wywołanym brakiem więzi emocjonalnej i mentalnej z innymi ludźmi (Szukalski, 2003). W przypadku doświadczania samotności przez ludzi starszych można stwierdzić, że najczęstszą jej przyczyną jest zanik modelu rodziny wielopokoleniowej, w której we wcześniejszych okresach osoby w podeszłym wieku znajdowały swoje miejsce oraz należny szacunek (Gajda, 1997). Nie bez znaczenia jest także płeć, poziom wykształcenia oraz stopień zamożności. Badania Kubickiego i Olcon-Kubickiej (2010) wskazują, że na ryzyko osamotnienia w sposób istotny bardziej narażone są: kobiety, osoby z wykształceniem podstawowym i niższym, renciści, mieszkańcy wsi i wschodniego regionu Polski, osoby ubogie i osoby mieszkające samotnie. Na ryzyko osamotnienia mniej narażeni są natomiast: mężczyźni, osoby z wykształceniem zawodowym lub wyższym, osoby aktywne zawodowo, mieszkańcy miast powyżej 500 tys. osób, osoby niemieszkające samotnie.

Osoby profesjonalnie opiekujące się osobami starszymi samotność definiowały raczej w kategoriach upokorzenia odczuwanego przez starszych ludzi ze strony społeczeństwa, które: „skazuje ich na dołującą egzystencję [...] najlepiej byłoby gdyby ich nie było, niech się nie pojawiają, bo to balast, powinno ich nie widać”. Tak samo spostrzegają samotność ludzi starych osoby młode: „są zepchnięci na margines, społeczeństwo ich nie potrzebuje, cichy kącik, odchować wnuki, to dla nich miejsce” (Kubicki, Olcon-Kubicka, 2010, s. 135). 


\section{WARTOŚĆ OSAMOTNIENIA}

Samo starzenie się może przybierać różnorodne postaci, od tych najmniej akceptowanych i negatywnych po bardzo pozytywne, zbudowane na aktywności i radości osób w podeszłym wieku. Może ona być odczuwana jako balast, niepotrzebny ciężar czy też kara, natomiast dla wielu - zwłaszcza wybierających samotność świadomie - może stanowić czas większej refleksji, radości z przebywania sam na sam ze sobą, odkrywania w sobie wartości do tej pory niepoznanych. Budować może również poczucie samowystarczalności i siły wewnętrznej. W literaturze przedmiotu mówi się wtedy o samotności pozytywnej, zbudowanej na własnej decyzyjności i poczuciu własnej wartości. Pomyślne starzenie się - wg Gryglewskiej - to: „osiągnięcie wieku starości obarczonego niewielkim ryzykiem chorób i niedołężności w połączeniu z wysoką sprawnością fizyczną i umysłową oraz zachowanie aktywności życiowej w sferze kontaktów społecznych i towarzyskich” (Szyszkowski, 2013, s. 491). W literaturze przedmiotu funkcjonuje termin active ageing skupiający swoją uwagę na czynnikach pozytywnego starzenia się. Termin ten został wprowadzany przez Światową Organizacje Zdrowia i Unię Europejską i prezentuje dwa wzory funkcjonowania. Pierwszy z nich wskazuje na niezbędność aktywności życiowej, prowadzącej ostatecznie do lepszego obrazu siebie i satysfakcji odczuwanej z własnego życia. Drugi model to skłonność do wycofywania się ludzi starych przez na przykład robienie miejsca ludziom młodym na rynku pracy. Oczywiście, WHO i UE pochwala i zachęca do pierwszego modelu funkcjonowania. Według formuły active ageing (Szyszkowski, 2013, s. 492) „osoby starsze mogą pozostać aktywne z powodzeniem zastępując utracone role nowymi, przynoszącymi korzyści zarówno im, jak i społeczeństwu”. Zgodnie z wytycznymi odbywa się to na trzech wymiarach:

1) wymiar aktywnego starzenia się na rynku pracy,

2) wymiar niezależnego życia,

3) wymiar udziału w życiu społecznym.

Takie funkcjonowanie osób starszych, realizujących zasady aktywnego starzenia się, prowadzi do: „tworzenia optymalnych możliwości w zakresie zdrowia, uczestnictwa i bezpieczeństwa w celu zwiększenia jakości życia ludzi w okresie starości” (Szyszkowski, 2013, s. 492). 


\section{PODSUMOWANIE}

Starzenie się wydaje się jednym z trudniejszych okresów ludzkiego życia. Powoduje nie tylko degradację lub ograniczenie sprawności fizycznej, zmniejszając możliwość spełniania wcześniejszych ról i wykonywania określonych aktywności; to również okres wielu strat emocjonalnych i społecznych. Rezultatem może być doświadczanie trudności i wszechogarniającego cierpienia we wszystkich sferach funkcjonowania. Jednym ze skutków jest znacząco doświadczana przez ludzi starych samotność. Wydaje się, że w procesie wspierania osób starszych nie ma złotego środka. Oprócz bowiem oddziaływań osób zaangażowanych profesjonalnie istotne znaczenie ma również podejście do własnego starzenia się osoby starszej. Umiejętność znalezienia w sobie motywacji i chęci do aktywnego życia w podeszłym wieku pozwala przeżyć późniejszą dorosłość w poczuciu satysfakcji, świadomości samego siebie i zaspokajania psychicznych potrzeb, bez odczuwania alienacji czy odrzucenia.

\section{Bibliografia}

Charchut, D. (2013). Samotność - interdyscyplinarny przegląd definicji. W: J. Zimny (red.), Samotność: rzeczywistość czy fikcja. Stalowa Wola: Wyd. KUL.

Danilewicz, W., Theiss, W. (red.) (2014). Pedagogika społeczna wobec zagrożeń człowieka i idei sprawiedliwości społecznej. Warszawa: Wydawnictwo Akademickie ŻAK.

Dąbrowska, P. (1992). Samotność ludzi starych i sposoby jej przeciwdziałania. Pobrane z: http://www.stowarzyszeniefidesetratio.pl/Presentations0/2011-2Dobrawska.pdf

Dunaj, B. (red.) (1999). Domowy Popularny Słownik Języka Polskiego. Warszawa: Wydawnictwo WILGA.

Gajda, J. (1997). Wartości w życiu człowieka. Prawda, miłość, samotność. Lublin: Wyd. UMCS.

Gutka, J.A. (2013). Sposoby zapobiegania samotności osób starszych. W: J. Zimny (red.), Samotność: rzeczywistość czy fikcja. Stalowa Wola. Wyd. KUL.

Hauziński, A. (2007). Psychologiczne koszty zmiany miejsca zamieszkania w okresie późnej dorosłości. W: A.I. Brzezińska i in. (red.), Zagrożenia rozwoju w okresie późnej dorosłości. Poznań: Wydawnictwo Fundacji Humaniora.

Janiszewska, M., Barańska, A. (red.) (2013). Samotność i osamotnienie osób starszych wiekiem. W: J. Zimny (red.). Samotność: rzeczywistość czy fikcja. Stalowa Wola: Wyd. KUL.

Jundziłł, E., Pawłowska, R. (red.) (2000). Pedagogika człowieka samotnego. Gdańsk: Gdańska Wyższa Szkoła Humanistyczna.

Klimowicz, G. (1988). Przeciwko bezradnej samotności. Warszawa: Nasza Księgarnia.

Kubicki, P., Olcon-Kubicka, M. (2010). Osamotnienie osób starszych w Polsce - skala, przejawy oraz sposoby przeciwdziałania zjawisku. 8. Studia Humanistyczne AGH. 
Kusztelak, E. (2009). Twórcza samotność? Funkcjonowanie społeczne osób osamotnionych w okresie wczesnej dorosłości. W: K.J. Szmidt (red.), Metody pedagogicznych badań nad twórczością. Łódź: Akademia Humianistyczno-Ekonomiczna.

Olearczyk, T.E. (2007). Sieroctwo i osamotnienie. Pedagogiczne problemy kryzysu współczesnej rodziny. Kraków: WSF-P „Ignatianum” Wyd. WAM.

Oleś, P.K. (2011). Psychologia człowieka dorosłego. Warszawa: Wyd. PWN.

Rembowski, J. (1992). Samotność. W: P. Dąbrowska (red.), Samotność ludzi starych i sposoby jej przeciwdziałania. Pobrane z: http://www.stowarzyszeniefidesetratio.pl/ Presentations0/2011-2Dobrawska.pdf

Stochmiałek, J. (2005). Samotność oraz starość w świetle koncepcji jakości życia. W: J. Twardowska-Rajewska (red.), Przeciw samotności. Poznań: WN UAM.

Straś-Romanowska, M. (1999). Kryzys środka życia - szansa rozwoju osobowego. Teraźniejszość - Człowiek - Edukacja, 4.

Szukalski, P. (2005). Poczucie samotności i osamotnienia wśród sędziwych seniorów a ich sytuacja rodzinna. Pobrane z: http://dspace.uni.lodz.pl:8080/xmlui/bitstream/ handle/11089/4103/Wsparcie_spoleczne_Poczucie_samotnosci.pdf?sequence=1

Szyszkowski, W. (2013). Samotność w kontekście starości. W: J. Zimny (red.), Samotność: rzeczywistość czy fikcja. Stalowa Wola: Wyd. KUL.

Tokaj, A. (2014). O smutku - troskach schyłku życia. Refleksje pedagogiczne. W: A. Tokaj (red.), Pedagogika społeczna wobec zagrożeń człowieka idei sprawiedliwości społecznej. V Zjazd Pedagogów Społecznych. Tom 2 (s. 402-419). Warszawa: Wyd. Akademickie „Żak”.

Wieczorowska-Tobis, K. (2011). Specyfika pacjenta starszego. W: K. Wieczorowska-Tobis i in. (red.), Fizjoterapia w geriatrii (s. 18-27). Warszawa: PZWL. 